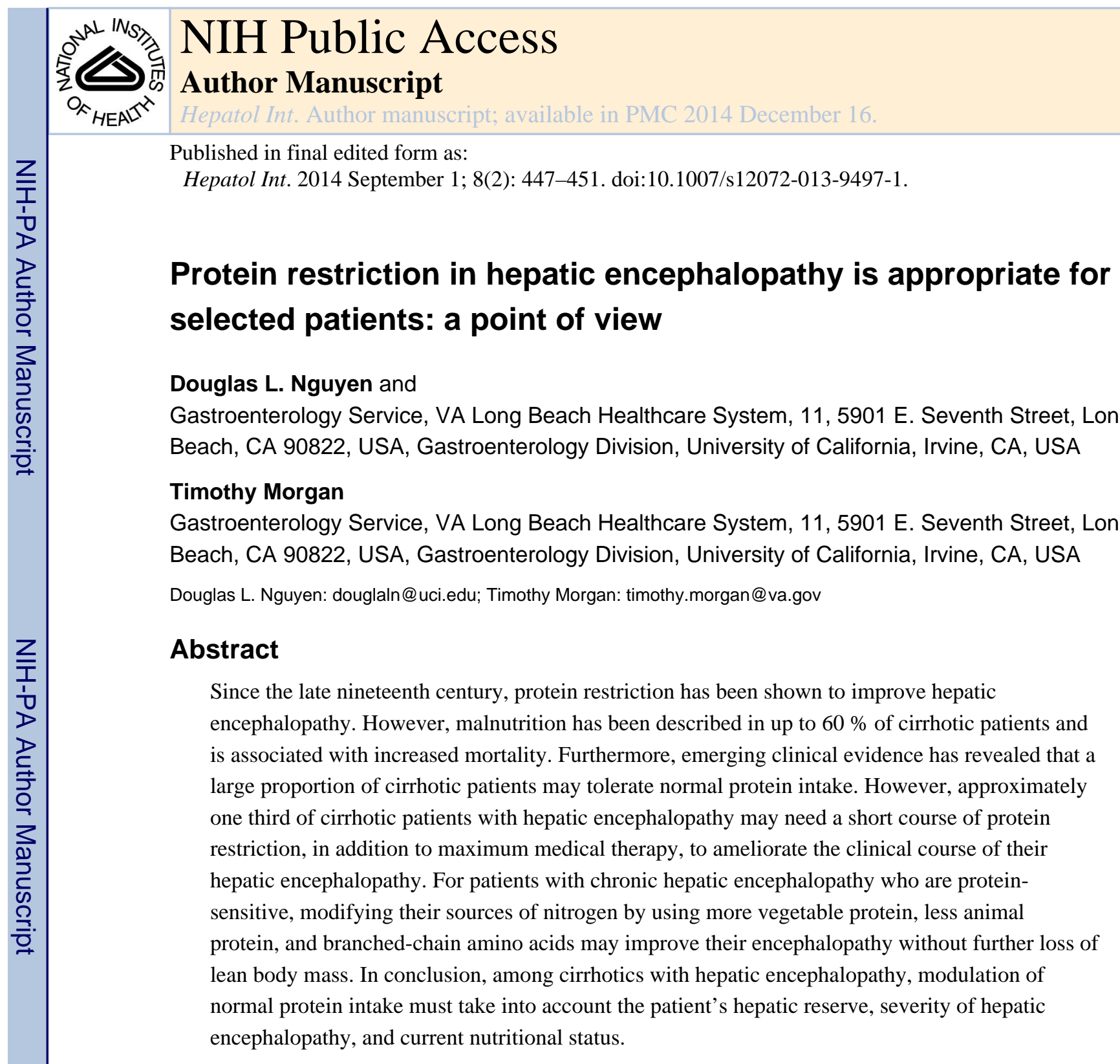

Keywords

Hepatic encephalopathy; Protein diet; Malnutrition

\title{
Introduction
}

Clinically, hepatic encephalopathy is a range of neuropsychiatric disturbances among patients with liver disease. It is characterized by personality changes, intellectual impairment, and altered level of consciousness. The manifestations of this syndrome range from mild abnormalities only detectable by psychometric testing to confusion and coma. The development of hepatic encephalopathy is a sign of decompensation and a marker of

(C) Asian Pacific Association for the Study of the Liver 2013

Correspondence to: Douglas L. Nguyen, douglaln@uci . edu.

Compliance with ethical requirements and Conflict of interest This article does not contain any studies with human or animal subjects by any of the authors. 
poor prognosis that may herald the need for transplantation. Important factors contributing to hepatic encephalopathy include degree of hepatocellular failure, portosystemic shunting, and such exogenous factors as infection and variceal bleeding [1].

The main tenet in the pathogenesis of hepatic encephalopathy is the concept that nitrogenous substances derived from the gut adversely affect brain function. It is theorized that putative neurotoxins enter the systemic circulation from the gut and cross the blood-brain barrier, where they change the function and morphology of astrocytes. A variety of toxins, including ammonia, gamma-aminobutyric acid-ergic (GABA-ergic), catecholamine pathways, and false neurotransmitters, have been described in experimental hepatic encephalopathy [2].

Several studies suggest that ammonia, derived from dietary protein that enters the gut, is a key factor in the pathogenesis of hepatic encephalopathy [3, 4]. Treatment of hepatic encephalopathy is based on suppression of precipitating factors and on reducing ammonia production. Intestinal production of ammonia can be reduced by restricting the intake of dietary protein and inhibiting urease-producing bacteria.

\section{Malnutrition in liver disease}

Among patients with decompensated disease, protein calorie malnutrition has been described for up to $60 \%$ of patients [5]. Population studies have demonstrated that malnutrition is a factor affecting the morbidity and/or mortality of patients with chronic liver disease [6,7]. Among cirrhotics, malnutrition has been associated with several complications, including variceal bleeding, refractory ascites, spontaneous bacterial peritonitis, and heptorenal syndrome $[2,8,9]$. The pathogenesis of malnutrition in cirrhotics is multifactorial. Contributing factors include inadequate dietary intake, impaired digestion, and altered metabolism.

For more than half a century, protein restriction has been one of the main treatments for hepatic encephalopathy [10-13]. Clinical observation has shown that high protein intake may worsen encephalopathy for $35 \%$ of cirrhotic patients [1]. The purpose of the lowprotein diet is to reduce intestinal ammonia production and thereby prevent exacerbation of hepatic encephalopathy. The dilemma for practicing clinicians is that resting energy expenditure is increased in patients with cirrhosis relative to their lean body mass [14]. Among cirrhotics, utilization of macronutrients is affected; excessive activation of lipolysis and utilization of fat stores, and switch from glycogenolysis to gluconeogenesis, are also observed $[15,16]$. Because muscle tissue is also important in removing circulating ammonia [17], loss of muscle mass may compound underlying encephalopathy [18]. Therefore, in the management of hepatic encephalopathy, special dietary manipulation and adjustment of the protein content of a patient's diet should always ensure appropriate nutritional support in patients with cirrhosis [19].

\section{Hepatic encephalopathy and protein intake}

Nitrogen metabolism is significantly involved in the development of hepatic encephalopathy in cirrhotic patients [20]. Therefore, modulation of this important relationship is necessary in the management of hepatic encephalopathy. 
Early clinical observation revealed that bouts of overt hepatic encephalopathy among patients with cirrhosis could be controlled by reducing protein intake [11]. The American College of Gastroenterology Practice Guidelines on Hepatic Encephalopathy recommend that for cirrhotic patients with acute encephalopathy, protein intake should be started at 0.5 $\mathrm{g} / \mathrm{kg} /$ day with subsequent progressive increase to $1.0-1.5 \mathrm{~g} / \mathrm{kg} /$ day, depending on patient tolerance [21].

In 2004 Cordoba et al. [22] published the first prospective, randomized controlled study among cirrhotics who received different amounts of dietary protein. Among a cohort of 62 patients, 30 were ultimately enrolled with 15 receiving normal protein and 15 receiving no protein. The main exclusion criteria were acute alcoholic hepatitis, GI hemorrhage, and terminal illness. All patients were evaluated and treated for their primary cause of hepatic encephalopathy. Patients were also given lactulose and neomycin. The low-protein group received no protein for three days, then protein intake was slowly increased to $1.2 \mathrm{~g} / \mathrm{kg} / \mathrm{day}$; the normal-protein group received the standard $1.2 \mathrm{~g} / \mathrm{kg} /$ day. At the end of the study, protein synthesis and degradation were similar in the two groups. Biochemical data (including ammonia) and clinical course of encephalopathy were also similar in the two groups.

The Cordoba study of 2004 had several limitations. Only 20 patients were analyzed and nearly one-third of enrolled patients died. Randomization, also, may have been inadequate, because there seemed to be inequalities between the two groups. For example, average baseline weight was $60 \mathrm{~kg}$ in the low-protein group and $69 \mathrm{~kg}$ in the normal-protein group. In addition, the tools used for nutritional assessment of the patients were unclear, and although patients with advanced liver disease are, typically, fluid overloaded with loss of lean body mass, this did not seem to have been taken into account. Finally, the type of dietary protein was not classified in the study. Therefore, the Cordoba study cannot be uniformly applied to all cirrhotic patients with acute hepatic encephalopathy or to stratify which cirrhotic patients may tolerate normal protein intake.

Despite its many limitations, the Cordoba study does suggest that for selected patients with acute hepatic encephalopathy who are on maximum medical therapy, nutrition support with standard protein supplementation at $1.2 \mathrm{~g} / \mathrm{kg} / \mathrm{day}$ may be tolerated. On the other hand, the Cordoba study also demonstrated that short-term protein restriction will not result in significant total body protein turnover and worsening clinical outcome. In cases of medically refractory hepatic encephalopathy, short-term protein restriction may be of clinical benefit, as observed in historical cohorts, without seriously harming total body protein turnover. However, it is unclear whether or not this is true for the severely malnourished. Modulation of protein intake by these patients must take all clinical observations into account, including an understanding of the patient's nutritional status, degree of hepatic encephalopathy, and hepatic reserve. 


\section{Dietary nitrogen sources}

\section{Sources of proteins}

Although the Cordova study suggests that not all patients with hepatic encephalopathy will require a protein-restricted diet, the study does not take into account the sources of protein. The type of protein consumed may be as important as the total amount of protein ingested. Cirrhotic patients have different tolerance of dietary protein. Several early studies have shown that dairy protein may be better tolerated than protein from mixed sources, and vegetable proteins are better tolerated than meat protein [23-26].

Vegetable protein diets contain more dietary fiber than isonitrogenous meat protein diets [20]. Fiber increases the rate of transit of food through the intestines, resulting in increased fecal ammonia excretion, and reduces the $\mathrm{pH}$ of the colonic lumen, which may result in a favorable microbiota [27-29]. Compared with meat-based protein, vegetable protein is poor in the sulfated amino acids methionine and cysteine, which are precursors of the mercaptans and indole and/or oxindole compounds which have been implicated in the pathogenesis of hepatic encephalopathy [30]. Vegetable proteins are high in ornithine and arginine, which facilitate ammonia disposal through the urea cycle [31].

Uribe et al. [32] demonstrated improvement in mental state, number connection test times, and electroencephalograms for patients with mild chronic hepatic encephalopathy on vegetable protein diet monotherapy compared with those on animal protein diets plus neomycin. In another controlled study, Bianchi et al. [33] enrolled patients with chronic hepatic encephalopathy despite being on maximum lactulose therapy and randomized them into two groups with equal caloric and equal nitrogenous diets for seven days. Improved nitrogen balance, reduced serum ammonia, and improved clinical grading and psychometric testing were observed for the group consuming vegetable protein.

As already mentioned, studies have demonstrated that a large proportion of cirrhotic patients can tolerate a high protein intake without induction or exacerbation of hepatic encephalopathy. However, it is also recognized that a subset of cirrhotics is proteinintolerant [34]. Gheorghe et al. [35] demonstrated that $80 \%$ of patients with hepatic encephalopathy were able to tolerate a high-calorie, high-casein-vegetable-based diet without further deterioration of mental status. However, 31 of the 122 enrolled patients required a brief course of protein restriction to $0.5 \mathrm{~g} / \mathrm{kg} /$ day, and clinical improvement of their encephalopathy was subsequently observed for nearly $70 \%$ of those patients.

A recent consensus statement from the International Society for Hepatic Encephalopathy and Nitrogen Metabolism recommends that patients with recurrent or persistent hepatic encephalopathy should consume a diet low in animal protein and rich in vegetable protein [20]. Typically, 30-40 g vegetable protein per day can usually be achieved, because higher levels may cause significant diarrhea and abdominal bloating, which may become intolerable for patients. However, it is important to recognize that, despite use of vegetablebased protein for patients with treatment-resistant hepatic encephalopathy, a subset of cirrhotics with acute encephalopathy might still benefit from a brief period of protein restriction. 


\section{Branched-chain amino acids}

The branched-chain amino acids (valine, leucine, and isoleucine) are essential amino acids which are metabolized by the skeletal muscle rather than by the liver. Plasma branchedchain amino acids are reduced in cirrhotics, whereas concentrations of aromatic amino acids, for example phenylalanine and tyrosine, are increased [36]. It has been postulated that the aromatic amino acids would flood the central nervous system, because aromatic amino acids and branched-chain amino acids compete for the same transporter to cross the blood brain barrier [37]. These imbalances between the aromatic amino acids and branched-chain amino acids result from a combination of poor hepatic function, portal-systemic shunting, hyperammonemia, hyperinsulinemia, and hyperglucagonemia [20].

In a multicenter study from Italy, Marchesini et al. [38] recruited patients with chronic hepatic encephalopathy confirmed by psychometric testing. Patients were randomized to either receiving branched-chain amino acids or placebo for eight weeks. At the end of the study, the group that received branched-chain amino acids had a statistically significant improvement in psychometric testing. A Cochrane review of 11 controlled studies, totaling 556 patients, suggests that supplements containing branched-chain acids favorably affect hepatic encephalopathy but have no effect on mortality [39]. However, in a randomized control study of 116 cirrhotics, branched-chain amino acids failed to prevent recurrent hepatic encephalopathy although they did result in improvement of muscle mass [40].

On the basis of the current literature it seems that among cirrhotics who are proteinintolerant, reducing the level of protein intake and supplementing with branched-chain amino acids may maintain lean body mass without aggravating hepatic encephalopathy. However, branched-chain amino acids should not be routinely used for patients with cirrhosis because they do not seem to improve overall mortality.

\section{Conclusions}

Malnutrition has been described for up to $60 \%$ of cirrhotic patients. Malnutrition among cirrhotics has been associated with multiple complications including variceal bleeding, refractory ascites, spontaneous bacterial peritonitis, and hepatorenal syndrome [2]. Malnutrition is also associated with poorer prognosis among this patient population [41].

Since the late nineteenth century, protein restriction has been shown to improve hepatic encephalopathy. Emerging clinical evidence suggests that a large a proportion of cirrhotic patients may tolerate a normal level of protein intake. However, approximately one third of cirrhotics with hepatic encephalopathy are protein-intolerant. In the subset of patients who are protein-intolerant, a short trial of protein restriction for a few days may ameliorate their hepatic encephalopathy without significant loss of total body protein turnover. Also, for patients with chronic hepatic encephalopathy who have worsening symptoms on a highprotein diet, substitution of nitrogen sources (i.e., vegetable protein or branched-chain amino acids) should be considered. Future studies are necessary to identify which group of cirrhotics would benefit from early protein restriction and the maximum duration for which these patients can undergo protein restriction. 
In conclusion, among cirrhotics with hepatic encephalopathy, modulation of normal protein intake must take into account the patient's hepatic reserve, severity of hepatic encephalopathy, and current nutritional status. Protein restriction, particularly protein from animal sources, should be a considered for patients with acute or chronic hepatic encephalopathy for whom other treatment modalities have failed to completely control symptoms.

\section{References}

1. Seymour CA, Whelan K. Dietary management of hepatic encephalopathy. BMJ. 1999; 318:13641365. [PubMed: 10334724]

2. Cabral CM, Burns DL. Low-protein diets for hepatic encephalopathy debunked: let them eat steak. Nutr Clin Practic. 2011; 26:155-159.

3. Butterworth RF. The neurobiology of hepatic encephalopathy. Semin Liver Dis. 1996; 16:235-244. [PubMed: 8989809]

4. Norenberg MD. Astrocytic-ammonia interactions in hepatic encephalopathy. Semin Liver Dis. 1996; 16:245-253. [PubMed: 8989810]

5. Lautz HU, Selberg O, Korber J, Bürger M, Müller MJ. Proteincalorie malnutrition in liver cirrhosis. Clin Investig. 1992; 70:478-486.

6. Sam J, Nguyen GC. Protein-calorie malnutrition as a prognostic indicator of mortality amont patients hospitalized with cirrhosis and portal hypertension. Liver Int. 2009; 29:1396-1402. [PubMed: 19602136]

7. Mendenhall CL, Tosch T, Weesner RE, Garcia-Pont P, Goldberg SJ, Kiernan T, et al. VA cooperative study on alcoholic hepatitis. II: prognostic significance of protein-calorie malnutrition. Am J Clinc Nutr. 1986; 43:213-218.

8. Kalman DR, Saltzman JR. Nutrition status predicts survical in cirrhosis. Nutr Rev. 1996; 54:217219. [PubMed: 8918144]

9. Merli M, Reggio O, Dally L. Does malnutrition affect survival in cirrhosis? Hepatology. 1996; 23:1041-1046. [PubMed: 8621131]

10. Soulsby CT, Morgan MY. Dietary management of hepatic encephalopathy in cirrhotic patients: survey of current practice in United Kingdom. BMJ. 1999; 318:1391. [PubMed: 10334749]

11. Phillips GB, Schwartz R, Gabuzda GJ, Davidson CS. The syndrome of impending hepatic coma in patients with cirrhosis of the liver given certain nitrogenous substances. N Engl J Med. 1952; 247:239-246. [PubMed: 14947933]

12. Riordan SM, Williams R. Treatment of hepatic encephalopathy. N Engl J Med. 1997; 337:413419.

13. Balo J, Korpassy B. The encephalitis of dogs with Eck fistula fed on meat. Arch Pathol. 1932; 13:80-87.

14. Mueller MJ, Bottcher J, Selberg O, Weselmann S, Böker KH, Schwarze M, et al. Hypermetabolism in clinically stable patients with liver cirrhosis. Am J Clin Nutr. 1999; 69:10661068. [PubMed: 10357723]

15. Petrides AS, Groop LC, Riely CA, DeFronzo RA, et al. Effect of physiologic hyperinsulinemia on glucose and lipid metabolism in cirrhosis. J Clin Invest. 1991; 88:561-570. [PubMed: 1864966]

16. Krahenbuhl L, Lang C, Ludes S, Seiler C, Schäfer M, Zimmermann A, et al. Reduced hepatic glycogen stores in patients with liver cirrhosis. Liver Int. 2003; 23:101-109. [PubMed: 12654132]

17. Olde Damink SW. Interorgan ammonia and amino acid metabolism in metabolically stable patients with cirrhosis and a TIPSS. Hepatology. 2002; 36:1163-1171. [PubMed: 12395326]

18. Merli M, Giusto M, Lucidi C, Giannelli V, Pentassuglio I, Gregorio V, et al. Muscle depletion increases the risk of overt and minimal hepatic encephalopathy: results of a prospective study. Metab Brain Dis. 2013; 28:281-284. [PubMed: 23224378] 
19. Plank LD, Gane EJ, Peng S, Muthu C, Mathur S, Gillanders L, et al. Nocturnal nutritional supplementation improves total body protein status of patients with liver cirrhosis: a randomized 12-month trial. Hepatology. 2008; 48:557-566. [PubMed: 18627001]

20. Amodio P, Bemeur C, Butterworth R, Cordoba J, Kato A, Montagnese S, et al. The nutritional management of hepatic encephalopathy in patients with cirrhosis: International Society for Hepatic Encephalopathy and Nitrogen Metabolism Consensus. Hepatology. 2011; 58:325-336. [PubMed: 23471642]

21. Blei AT, Cordoba J. Practice Parameters Committee of the American College of Gastroenterology. Hepatic encephalopathy. Am J Gastroenterol. 2001; 96:1968-1976. [PubMed: 11467622]

22. Cordoba J, Lopez-Hellin J, Planas M, et al. Normal protein diet for episodic hepatic encephalopathy: results of a randomized study. J Hepatol. 2004; 41:38-43. [PubMed: 15246205]

23. Bessman AN, Mirick GS. Blood ammonia levels following the ingestion of casein and whole blood. J Clin Invest. 1958; 37:990-998. [PubMed: 13563627]

24. Fenton JC, Knight EJ, Humpherson PL. Milk-and-cheese diet in portal-systemic encephalopathy. Lancet. 1966; 1:164-166. [PubMed: 4159095]

25. Greenberger NJ, Carley J, Schenker S, et al. Effect of vegetable and animal protein diets in chronic hepatic encephalopathy. Am J Dig Dis. 1977; 22:845-855. [PubMed: 335882]

26. Weber FL, Mino D, Fresard KM, Banwell JG. Effects of vegetable diets on nitrogen metabolism in cirrhotic subjects. Gastroenterology. 1985; 89:538-544. [PubMed: 2991068]

27. Uribe M, Dibildox M, Malpaica S, Guillermo E, Villallobos A, Nieto L, et al. Beneficial effect of vegetable protein diet supplemented with psyllium plantago in patients with hepatic encephalopathy and diabetes mellitus. Gastroenterology. 1985; 88:901-907. [PubMed: 2982694]

28. Vester Boler BM, Faber TA, Bauer LL, Swanson KS, Smiley S, Bechtel PJ, et al. Acute satiety response of mammalian, avian and fish proteins in dogs. Br J Nutr. 2012; 107:146-154. [PubMed: 21733332]

29. Bosscher D, Breynaert A, Pieters L, Hermans N. Food-based strategies to modulate the composition of the intestinal microbiota and their associated health effects. J Physiol Pharmacol. 2009; 60(Suppl 6):5-11. [PubMed: 20224145]

30. Zieve L, Doizaki WM, Zieve J. Synergism between mercaptans and ammonia or fatty acids in the production of coma: a possible role for mercaptans in the pathogenesis of hepatic coma. J Lab Clin Med. 1974; 83(1):16-28. [PubMed: 4808653]

31. de Bruijn KM, Blendis LM, Zilm DH, Carlen PL, Anderson GH, et al. Effect of dietary protein manipulation in subclinical portalsystemic encephalopathy. Gut. 1983; 24(1):53-60. [PubMed: 6336714]

32. Uribe M, Marquez MA, Garcia Ramos G, Ramos-Uribe MH, Vargas F, Villalobos A. Treatment of chronic portal-systemic encephalopathy with vegetable and animal protein diets. A controlled crossover study. Dig Dis Sci. 1982; 27(12):1109-1116. [PubMed: 6756833]

33. Bianchi GP, Marchesni G, Fabbri A, Rondelli A, Bugianesi E, Zoli M, et al. Vegetable versus animal protein diet in cirrhotic patients with chronic encephalopathy. A randomized cross-over comparison. J Intern Med. 1993; 233:385-392. [PubMed: 8068051]

34. Swart GR, van den Berg JW, van Vuure JK, Rietveld T, Wattimena DL, Frenkel M. Minimum protein requirements in liver cirrhosis determined by nitrogen balance measurements at three levels of protein intake. Clin Nutr. 1989; 8(6):329-336. [PubMed: 16837309]

35. Gheorghe L, Iacob R, Vandan R, Iacob S, Gheorghe C. Improvement of hepatic encephalopathy using a modified highcalorie high-protein diet. Rom J Gastroenterol. 2005; 14:231-238. [PubMed: 16200232]

36. Morgan MY, Milsom JP, Sherlock S. Plasma ratio of valine, leucine and isoleucine to phenylalanine and tyrosine in liver disease. Gut. 1978; 19(11):1068-1073. [PubMed: 730076]

37. Fischer JE, Baldessarini RJ. False neurotransmitters and hepatic failure. Lancet. 1971; 2(7715):7580. [PubMed: 4103986]

38. Marchesini G, Dioguardi FS, Bianchi GP, Zoli M, Bellati G, Roffi L, et al. The Italian Multicenter Study Group. Long-term oral branched-chain amino acid treatment in chronic hepatic encephalopathy. A randomized doubleblind casein-controlled trial. J Hepatol. 1990; 11:92-101. [PubMed: 2204661] 
39. Als-Nielsen B, Koretz RL, Kjaergard LL, Gluud C. Branchedchain amino acids for hepatic encephalopathy. Cochrane Database Syst Rev. 2003; 2:CD001939. [PubMed: 12804416]

40. Les I, Doval E, Garcia-Martinez R, Planas M, Cárdenas G, Gómez P, et al. Effects of branchedchain amino acids supplementation in patients with cirrhosis and a previous episode of hepatic encephalopathy: a randomized study. Am J Gastroenterol. 2011; 106:1081-1088. [PubMed: 21326220]

41. Mendenhall CL, Mortiz TE, Roselle GA, Morgan TR, Nemchausky BA, Tamburro CH, et al. A study of oral nutritional support with oxandrolone in malnourished patients with alcoholic hepatitis: results of a Department of Veterans Affairs cooperative study. Hepatology. 1993; 17:564-576. [PubMed: 8477961] 